\title{
Media Attention for Jerusalem Declaration: a Comparative Discourse Analysis on International Online Newspapers
}

\author{
Muhammad Rayhan Bustam \\ English Department \\ Universitas Komputer Indonesia \\ Bandung, Indonesia \\ muhammad.rayhan@email.unikom.ac.id
}

\begin{abstract}
- this study examines the discourse strategies used in the news headings in representing the social actors related to the case of Donald Trump's declaration to Jerusalem as Israel Capital. The study employs Critical Discourse Analysis (CDA) to analyze the representation of political social actors in the case. In addition, it also describes the linguistic realization of the strategies and the function of strategies use in representing the actors. Three international online newspapers are chosen systematically as representative media which released the news related to the case; the newspapers are: CNN News, The Guardian, and Al Jazeera. The study uses the theory of representation of social actors put forward by Theo van Leeuwen (2008). The theory involves a socio-semantic network of social actors. In the network, it is presented two main divisions, exclusion (process of omitting actors) and inclusion (process of presenting social actor(s) in a representation). The results show that there are some different techniques and discourse strategies in presenting the representation of political social actors related to the case. Thus, it can be concluded that the different representation used by each media is because of its own ideology and its believe in framing the case.
\end{abstract}

Keywords-CDA, International Online Media, Jerusalem Declaration

\section{INTRODUCTION}

The present study entitled "Media Attention for Jerusalem Declaration: A Comparative Discourse Analysis on International Online Newspapers" employs Critical Discourse Analysis (CDA) to analyze the representation of political social actors in the case of Donald Trump's declaration to Jerusalem as the capital of Israel. The study examines the discourse strategies, the linguistic realization of the strategies, and the function of using the strategies in representing the social actors used in the headings of three international online newspapers: CNN News, The Guardian, and Al Jazeera. The three online newspapers are chosen systematically as representative media which released the news related to the case. CNN News accessed in www.cnn.com is considered as a representative of US media which is related in the case as the country of the claimer, Donald Trump; The Guardian accessed in www.theguardian.com is considered as a representative of Europe media since the media has quite big influence to the European readers; and, Al Jazeera accessed in www.aljazeera.com is considered as a representative of Moslem media since the media has a big influence to the Moslem readers in the world. A comparative analysis is performed to the three online newspapers by using Leeuwen's theory of representation of social actors (2008).

Related to the present study, there are some previous pieces of study. First, the study is entitled "Event and Actors Representation in Selected Nigerian Daily Newspaper" by Asiru, Ogutu, and Orwenjo. In the study, the writers use mixed theories between Leeuwen's representation of social actor and Halliday's Systemic Functional Linguistic (SFL) [1]. However, their results of study does not cover Leeuwen's social actor network completely, and even only more focuses on the SFL approach. Second, the study is entitled "Inclusion of Murder News in Posmetro Padang Daily Newspaper: A Study of Critical Discourse Analysis" by Fitri and Rahmat. They use similar theory to the present study, Leeuwen's representation of social actor [2]. However, they only focus on inclusion strategies meanwhile the present study covers not only inclusion but also exclusion strategies. Third, the study is entitled "Representations of Social Actors in J. Khrisnamurti and Alan Watts' Philosophical Speech: A Critical Discourse Analysis" by Dashti and Mehrpour. In the study, the writers use the theory of Leeuwen's representation of social actor [3]. However, their study focuses on implementing the theory to the participants involved on the content of the speeches, while the present study focuses more how the text producer, the newspaper, represent the political social actors through some specific mechanism and linguistics realization. Forth, the study is entitled "The Representations of Social Actors in The Graduate Employability Issue: Online News and The Government Document" by S.N.F Mohd Noor. The writer uses a comparative analysis in her study, and also uses a CDA approach [4]. However, the things compared are not in similar level because the writer compares text in some newspapers published in Malaysia to the government document; while in the present study conducts a comparative study in the same level source, the text in newspapers. In addition, the writer uses the CDA approach theory by Fairclough and supported by transitivity analysis approach theory by Halliday [5] for describing the linguistics aspect in the analysis while the present study gives more compact tools for analysis, the theory of representation of social actors by van Leeuwen; the theory gives network and specific linguistic realizations to support the analysis.

Furthermore, the present writer has also conducted a study entitled "The Exclusion Strategies of the Representation of Social Actors in the Case of FPI's 
Rejection to Lady Gaga's Performance in Indonesia on The Jakarta Post Newspaper Headlines (A CDA Approach)". In the study, the present writer uses similar theory to the present study, Leeuwen's representation of social actor [6]. However, it is only focused on exclusion strategies meanwhile the present study is developed to cover both exclusion and inclusion strategies.

All the previous pieces of study do not compeletely cover the theory of representation of social actors by van Leeuwen and even the previous study must use supporting theories of Systemic Functional Linguistics (SFL) in revealing the linguistics aspect for analysis. However, the present study, uses only the theory of representation of social actors by van Leeuwen since the theory has already given all tools needed for analysis, such as: network and specific linguistic realizations to support the analysis. All is done by the present writer to give a deeper description and a clearer analysis.

Regarding to the case of the present study, inspired by the previous study entitled "Critical Discourse Analysis in Donald Trump Presidential Campaign to win American's Heart" by Rachman and Yunianti [7], Donald Trump's declaration to Jerusalem as the Capital of Israel is chosen as the case focus. The declaration case has shocked the world since Jerusalem considered as the holy city for three religions: Islam, Jewish, and Christian; even, the city area is still in dispute between Palestinians and Israeli. The news related to the case is interesting to investigate since the news can give a significant impact to the world; moreover, how the news is presented and how the social actors are represented from three international online media: CNN, The Guardian, and Aljazeera become the object of the present study.

Therefore, the objectives of the present study are to discover the discourse strategies, the linguistic realization of the strategies, and the function of using the strategies in representing the social actors used in the headings of the three online media related to the declaration case. In addition, the method used in the study is qualitative, and the present writer uses descriptive method to present the analysis in discussion.

\section{METHOD}

The method applied in the present study is qualitative. Flick stated, "Qualitative research is centrally concerned with the production and analysis of texts" [8]. In addition, Mason also stated that qualitative research is "the ways that social processes, institutions, discourses or relationships work, and the significance of the meanings that they generate" [9]. Related to both quotations above, the present study focuses on how the text, in this case the news heading, is produced and analyzed based on the discourse strategies and the language realization of the strategies.

In implementing the method, the present writer gives some attempts as the parts of process in the present study. One of the attempts is by deciding the news topic to raise and the main attention to see for the present study. The present writer chooses the Donald Trump's declaration to Jerusalem as the Capital of Israel as the news topic, and as the present study focuses on the representation of social actors, the main attention to see is the actors involved in the case.

After the social actors are identified, the next attempt is to conduct specific strategies to ensure the process in line with the objectives of the study. In completing the first objective, the present writer refers to the social actor network to find the discourse strategies of representation of social actors put forward by van Leeuwen (2008). Then, in completing the second objective, through the network, the present writer also uses Leeuwen's specific linguistic realization on discourse strategies of representation of social actors. Lastly, in implementing the third objective, the present writer formulates the functions why the online media uses the strategies based on the analysis processes made before.

Figure 1 shows the network needed to pay attention when completing the first and the second objectives. The network called sociosemantic network of social actors is divided into two main divisions or strategies: exclusion and inclusion. Exclusion is the process of omitting actors by some linguistic mechanisms. It has two main subdivisions: suppression and backgrounding. The main difference between suppression and backgrounding is the point that they leave trace or not within representation [10].

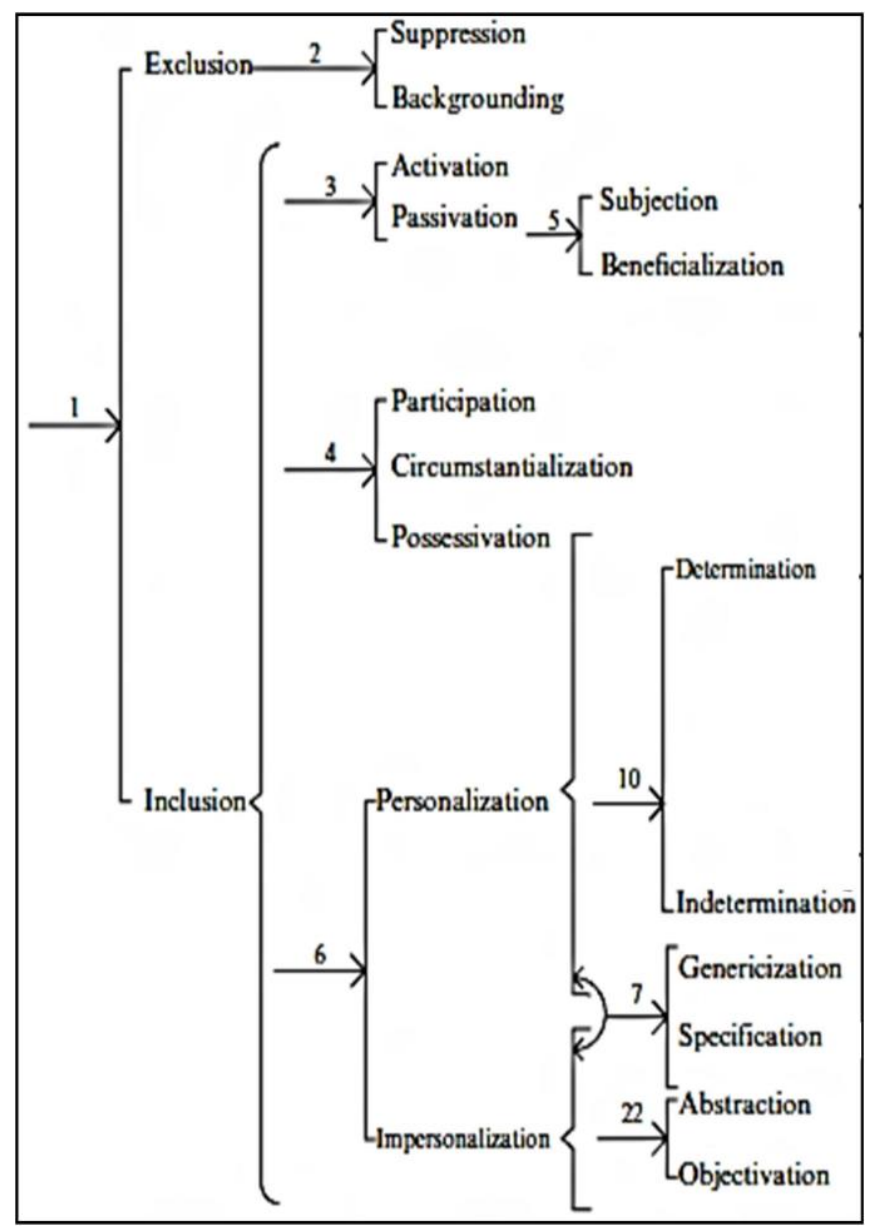

Fig. 1. Social Actor Network

Inclusion is the process of presenting social actor(s) in a representation. Here, it is related to how the social actor(s) is presented in a text or news. Inclusion is divided into two main subdivisions: personalization and impersonalization. According to van Leeuwen, personalization means the representation of social actors as human beings, whereas impersonalization is representation of social actors by other means (not human beings). Then, the divisions are subdivided into genericization-specification, indetermination - determination, and abstraction - objectivation. 


\section{RESULTS}

The results of the present study show that all of media CNN, Al Jazeera, or The Guardian uses both of exclusion and inclusion strategies. Each media also uses specific linguistic realization as shown in Table 1.

TABLE I. ANALYSIS OF STRATEGY AND LINGUISTIC REALIZATION

\begin{tabular}{|c|c|c|c|c|}
\hline \multirow[b]{2}{*}{ Media } & \multirow{2}{*}{$\begin{array}{l}\text { Relea } \\
\text { sed }\end{array}$} & \multicolumn{3}{|c|}{ Analysis } \\
\hline & & Data & Strategy & $\begin{array}{l}\text { Linguistic } \\
\text { Realization }\end{array}$ \\
\hline $\begin{array}{l}\text { Al Jazeera } \\
\text { (www. } \\
\text { Aljazeera.c } \\
\text { om) }\end{array}$ & $\begin{array}{l}\text { Dece } \\
\text { mber } \\
2017\end{array}$ & $\begin{array}{l}\text { 1. Trump's } \\
\text { Jerusalem move } \\
\text { roundly } \\
\text { condemned at } \mathbf{U N}\end{array}$ & Inclusion & $\begin{array}{l}\text { Individualiza- } \\
\text { tion \& } \\
\text { Genericization }\end{array}$ \\
\hline $\begin{array}{l}\text { Al Jazeera } \\
\text { (www. } \\
\text { Aljazeera.c } \\
\text { om) }\end{array}$ & $\begin{array}{l}\text { Dece } \\
\text { mber } \\
2017\end{array}$ & $\begin{array}{l}\text { 2. World leaders } \\
\text { chastise US over } \\
\text { Jerusalem } \\
\text { 'escalation' } \\
\end{array}$ & Inclusion & Genericization \\
\hline $\begin{array}{l}\text { Al Jazeera } \\
\text { (www. } \\
\text { Aljazeera.c } \\
\text { om) }\end{array}$ & $\begin{array}{l}\text { Dece } \\
\text { mber } \\
2017\end{array}$ & $\begin{array}{l}\text { 3. World reacts to } \\
\text { US Israel } \\
\text { embassy } \\
\text { relocation plan }\end{array}$ & $\begin{array}{l}\text { Inclusion \& } \\
\text { Exclusion }\end{array}$ & $\begin{array}{l}\text { Genericization } \\
\& \text { Suppression }\end{array}$ \\
\hline $\begin{array}{l}\text { Al Jazeera } \\
\text { (www. } \\
\text { Aljazeera.c } \\
\text { om) }\end{array}$ & $\begin{array}{l}\text { Dece } \\
\text { mber } \\
2017\end{array}$ & $\begin{array}{l}\text { 4. Thousands rally } \\
\text { in Jakarta against } \\
\text { US Jerusalem } \\
\text { move }\end{array}$ & Inclusion & Assimilation \\
\hline $\begin{array}{l}\text { Al Jazeera } \\
\text { (www. } \\
\text { Aljazeera.c } \\
\text { om) }\end{array}$ & $\begin{array}{l}\text { Dece } \\
\text { mber } \\
2017\end{array}$ & $\begin{array}{l}\text { 5. Social media } \\
\text { reaction: Arabs } \\
\text { helpless and } \\
\text { hopeless }\end{array}$ & Inclusion & Genericization \\
\hline $\begin{array}{l}\text { Al Jazeera } \\
\text { (www. } \\
\text { Aljazeera.c } \\
\text { om) }\end{array}$ & $\begin{array}{l}\text { Janua } \\
\text { ry } \\
2018\end{array}$ & $\begin{array}{l}\text { 6. Donald Trump } \\
\text { threatens cutting } \\
\text { off aid to } \\
\text { Palestinians }\end{array}$ & Inclusion & $\begin{array}{l}\text { Individualiza- } \\
\text { tion \& } \\
\text { Genericization }\end{array}$ \\
\hline $\begin{array}{l}\text { CNN } \\
\text { (www.editi } \\
\text { on.cnn.co } \\
\text { m) }\end{array}$ & $\begin{array}{l}\text { Dece } \\
\text { mber } \\
2017\end{array}$ & $\begin{array}{l}\text { 7. Trump's } \\
\text { Jerusalem } \\
\text { decision: How } \\
\text { the world reacted }\end{array}$ & Inclusion & $\begin{array}{l}\text { Individualiza- } \\
\text { tion \& } \\
\text { Genericization }\end{array}$ \\
\hline $\begin{array}{l}\text { CNN } \\
\text { (www.editi } \\
\text { on.cnn.co } \\
\text { m) }\end{array}$ & $\begin{array}{l}\text { Dece } \\
\text { mber } \\
2017\end{array}$ & $\begin{array}{l}\text { 8. Protests break out } \\
\text { following } \\
\text { Trump's } \\
\text { Jerusalem } \\
\text { decision } \\
\end{array}$ & $\begin{array}{l}\text { Exclusion \& } \\
\text { Inclusion }\end{array}$ & $\begin{array}{l}\text { Suppression \& } \\
\text { Individualiza- } \\
\text { tion }\end{array}$ \\
\hline $\begin{array}{l}\text { CNN } \\
\text { (www.editi } \\
\text { on.cnn.co } \\
\text { m) }\end{array}$ & $\begin{array}{l}\text { Dece } \\
\text { mber } \\
2017\end{array}$ & $\begin{array}{l}\text { 9. 'Jerusalem is our } \\
\text { right': } \\
\text { Palestinians } \\
\text { enraged by } \\
\text { Trump decision }\end{array}$ & Inclusion & $\begin{array}{l}\text { Differentiatio } \\
\mathrm{n}, \\
\text { Genericization } \\
\& \\
\text { Individualiza- } \\
\text { tion }\end{array}$ \\
\hline $\begin{array}{l}\text { CNN } \\
\text { (www.editi } \\
\text { on.cnn.co } \\
\text { m) }\end{array}$ & $\begin{array}{l}\text { Dece } \\
\text { mber } \\
2017\end{array}$ & $\begin{array}{l}\text { 10. Erdogan defies } \\
\text { Trump, says } \\
\text { Turkey has own } \\
\text { embassy plans for } \\
\text { Jerusalem }\end{array}$ & Inclusion & $\begin{array}{l}\text { Individualiza- } \\
\text { tion }\end{array}$ \\
\hline $\begin{array}{l}\text { CNN } \\
\text { (www.editi } \\
\text { on.cnn.co } \\
\text { m) }\end{array}$ & $\begin{array}{l}\text { Janua } \\
\text { ry } \\
2018\end{array}$ & $\begin{array}{l}\text { 11. Trump threatens } \\
\text { aid to } \\
\text { Palestinians, } \\
\text { appears to } \\
\text { contradict } \\
\text { himself on } \\
\text { Jerusalem } \\
\end{array}$ & Inclusion & $\begin{array}{l}\text { Individualiza- } \\
\text { tion \& } \\
\text { Genericization }\end{array}$ \\
\hline $\begin{array}{l}\text { The } \\
\text { Guardian } \\
\text { (www.theg } \\
\text { uardian.co } \\
\text { m) }\end{array}$ & $\begin{array}{l}\text { Dece } \\
\text { mber } \\
2017\end{array}$ & $\begin{array}{l}\text { 12. Trump risks } \\
\text { backlash as he } \\
\text { prepares to } \\
\text { recognise } \\
\text { Jerusalem as } \\
\text { Israel's capital }\end{array}$ & Inclusion & $\begin{array}{l}\text { Individualiza- } \\
\text { tion }\end{array}$ \\
\hline $\begin{array}{l}\text { The } \\
\text { Guardian } \\
\text { (www.theg } \\
\text { uardian.co } \\
\text { m) }\end{array}$ & $\begin{array}{l}\text { Dece } \\
\text { mber } \\
2017\end{array}$ & $\begin{array}{l}\text { 13. Trump's } \\
\text { Jerusalem } \\
\text { declaration draws } \\
\text { mixed reactions } \\
\text { from Jewish } \\
\text { Americans }\end{array}$ & Inclusion & $\begin{array}{l}\text { Individualiza- } \\
\text { tion \& } \\
\text { Genericization }\end{array}$ \\
\hline $\begin{array}{l}\text { The } \\
\text { Guardian } \\
\text { (www.theg } \\
\text { uardian.co } \\
\text { m) }\end{array}$ & $\begin{array}{l}\text { Dece } \\
\text { mber } \\
2017\end{array}$ & $\begin{array}{l}\text { 14. Donald Trump } \\
\text { risks 'destroying } \\
\text { peace hopes of } \\
\text { Israelis and } \\
\text { Palestinians' }\end{array}$ & Inclusion & $\begin{array}{l}\text { Individualiza- } \\
\text { tion \& } \\
\text { Genericization }\end{array}$ \\
\hline $\begin{array}{l}\text { The } \\
\text { Guardian } \\
\text { (www.theg } \\
\text { uardian.co } \\
\text { m) }\end{array}$ & $\begin{array}{l}\text { Dece } \\
\text { mber } \\
2017\end{array}$ & $\begin{array}{l}\text { 15. Writers, actors } \\
\text { and musicians } \\
\text { condemn Trump } \\
\text { Jerusalem move }\end{array}$ & Inclusion & $\begin{array}{l}\text { Functionaliza- } \\
\text { tion \& } \\
\text { Individualiza- } \\
\text { tion }\end{array}$ \\
\hline
\end{tabular}

\begin{tabular}{|c|c|c|c|c|}
\hline \multirow{2}{*}{ Media } & \multirow{2}{*}{$\begin{array}{c}\text { Relea } \\
\text { sed }\end{array}$} & \multicolumn{3}{|c|}{ Analysis } \\
\hline & & Data & Strategy & $\begin{array}{l}\text { Linguistic } \\
\text { Realization }\end{array}$ \\
\hline $\begin{array}{l}\text { The } \\
\text { Guardian } \\
\text { (www.theg } \\
\text { uardian.co } \\
\text { m) }\end{array}$ & $\begin{array}{l}\text { Dece } \\
\text { mber } \\
2017\end{array}$ & $\begin{array}{l}\text { 16. Trump threatens } \\
\text { to cut aid to } \\
\text { countries over } \\
\text { UN Jerusalem } \\
\text { vote }\end{array}$ & Inclusion & $\begin{array}{l}\text { Individualiza- } \\
\text { tion \& } \\
\text { Genericization }\end{array}$ \\
\hline
\end{tabular}

Data 1 to Data 6 are from Al Jazeera. In Datum 1, there are two social actors involved: 'Trump' and 'UN'. Here, 'Trump' is individualized from his country United States (US) while 'United Nation (UN)' is generalized from the countries under it; both of linguistic realizations are under inclusion strategies subdivision. In Datum 2, either the actor 'World leaders' or 'US', generalized from the citizens in it, is categorized genericization under inclusion strategies. In Datum 3, both of inclusion and exclusion strategies are involved; world is categorized genericization under inclusion strategies while the process Noun 'plan' is categorized suppression which omit the actor 'the planner' under exclusion strategy. Datum 4, the indefinite numbers 'thousands' is categorized Assimilation with aggregation as its specific linguistic realization under inclusion strategy. In Datum 5, 'Arabs' is categorized genericization under inclusion strategy. In Datum 6, 'Donald Trump' is individualization while 'Palestinians' is genericization; both of linguistic realizations are under inclusion strategy.

Data 7 to Data 11 are from CNN. In Datum 7, 'Trump' is individualization while 'Palestinians' is genericization; both of linguistic realizations are under inclusion strategy. In Datum 8, there is a process Noun 'protests'. The Noun is part of exclusion strategy which omits the actor 'the protester' from the text; it is categorized suppression. Besides, 'Trump' is individualization under inclusion strategy. In Datum 9, there is pronoun 'our'; the pronoun is categorized differentiation. Differentiation is when an individual social actor or group of social actors is differentiated, commonly with pronoun 'us/our' vs. 'them/their'. Besides, 'Palestinians' is categorized genericization, and 'Trump' is individualization; all of linguistic realizations are under inclusion strategies. In Datum 10, both 'Erdogan' and 'Trump' are individualized from their country; thus, it is categorized individualization which is under inclusion strategy. In Datum 11, 'Trump' and pronoun 'himself' are categorized individualization while 'Palestinians' is genericization; all of linguistic realizations are under inclusion strategy.

Data 12 to Data 16 are from The Guardian. In Datum 12, 'Trump' and pronoun 'he' are categorized individualization which is under inclusion strategy. In Datum 13, 'Trump' is individualization while 'Jewish Americans' is genericization; both of linguistic realizations are under inclusion strategy. In Datum 14, 'Donald Trump' is individualization while 'Israelis' and 'Palestinians' are genericization; all of linguistic realizations are under inclusion strategy. In Datum 15 , 'the writers', 'actors', and 'musicians' are categorized functionalization. The realization exists when social actors are referred to in terms of an activity, in terms of something they do, for instance, an occupation or role. This is also part of inclusion strategy. In Data 16, 'Trump' is individualization while 'countries' is genericization; both of linguistic realizations are under inclusion strategy. 


\section{DISCUSSION}

Based on the results, it can be compared between the online media $\mathrm{Al}$ Jazeera, $\mathrm{CNN}$ and The Guardian. In $\mathrm{Al}$ Jazeera, it is found $86 \%$ of inclusion strategy, and $14 \%$ of exclusion strategy as its discourse strategy presented in the headings of the news. In CNN, it is found $83 \%$ of inclusion strategy, and $17 \%$ of exclusion strategy as its discourse strategy presented in the headings of the news. In The Guardian, it is found $100 \%$ of inclusion strategy as its discourse strategy presented in the headings of the news. As van Leeuwen stated that "exclusion is the process of omitting actors", the comparison fact shows that The Guardian is more factual in releasing the news and raising the headings of the news, without attempting news smoothing through using exclusion strategy.

Related to the linguistic realizations used by each media, almost all Data from Al Jazeera found are genericization while all Data from CNN and The Guardian found are individualization. The comparison fact tends to give a formulation of the function why the media uses the strategy and the linguistic realization. The function of Al Jazeera using more genericization linguistic realization which is part of inclusion strategy is to drive their readers' thought that many parties and even countries in the world which are effected by US or Trump's declaration to Jerusalem as the capital of Israel; besides, Al Jazeera wants to show the readers that many parties and even countries in the world which dislike to the declaration. This also can be a strategy for Al Jazeera to direct the readers' empathy to the victim, in this case 'the Palestinians'. It is also clearly shown in Datum 1. Here, Al Jazeera uses ' $U N$ ' instead of 'some representative countries in UN' to generalize the institution. The main reason is to build the readers' perspective that many countries in UN do not agree with Trump's declaration. In the other side, Trump himself is represented as individualization; this is attempted by Al Jazeera to drive the readers' thought that what Trump does is not definitely supported by US people. In addition, in Datum 4, Al Jazeera uses assimilation realization by putting indefinite numbers 'thousands'; this is attempted to build readers' perspective that there are a lot of people in the world disagreeing or contra with the declaration.

In fact, both CNN and The Guardian tend to use more individualization linguistic realization which is part of inclusion strategy. Almost all of the individualizations refer to Donald Trump himself. The function of both media attempt this is to save United States from the negative view of parties and countries in the world. Besides, the media tends to show the world that not all Americans support the Trump's declaration. However, in another perspective, the individualizations use referring to Donald Trump can build Trump's image as a strong and powerful political actor; and, it can be affected to the countries in the world to give more respect to Donald Trump himself.

\section{CONCLUSION}

After completing the study, it can be concluded that every media has its own ideology, and represent what its believe in presenting the news. There are some different techniques or discourse strategies, and linguistic realizations in presenting the representation of political social actors in the headings of the news. The tendency of specific discourse strategies and linguistic realizations used by media is based on the media needs and function to drive readers' thought and attention in viewing a definite case.

\section{ACKNOWLEDGMENT}

The present writer gratefully acknowledge the support and generosity Rector of UNIKOM, Dean of Literary Faculty, and Head of English Department; without whom the present study could not have been completed.

\section{REFERENCES}

[1] H. T. Asiru, E. A Ogutu, and D. O. Orwenjo, "Event and Actors Representation in Selected Nigerian Daily Newspaper," Ghana Journal of Linguistics, vol. 7.1, pp. 84-104, 2018.

[2] R. Fitri and W. Rahmat, "Inclusion of Murder News in the Posmetro Padang Daily Newspaper: A Study of Critical Discourse Analysis," Humaniora, vol. 8 No. 4, pp. 311-317, October 2018.

[3] L. Dashti and S. Mehrpour, "Representations of Social Actors in J. Khrisnamurti and Alan Watts' Philosophical Speech: A Critical Discourse Analysis," Journal of Applied Linguistics and Language Research, Volume. 4, Issue 4, pp. 51-59, 2017

[4] S.N.F. Mohd Noor, "The Representations of Social Actors in The Graduate Employability Issue: Online News and The Government Document," International Journal of Society, Culture, and Language, Vol. 5(1), pp. 81-93, 2017.

[5] M.A.K. Halliday and C.M.I.M Matthiessen. An Introduction to Functinal Grammar. Third Edition. Australia: Oxford University Press Inc.

[6] M. R. Bustam, Heriyanto, and E. Citraresmana, "The Exclusion Strategies of the Representation of Social Actors in the Case of FPI's Rejection to Lady Gaga's Performance in Indonesia on The Jakarta Post Newspaper Headlines (A CDA Approach)," International Journal of Language Learning and Applied Linguistics World (IJLLALW), Vol. 4 (3), pp. 30-43, November 2013.

[7] A. Rachman and S. Yunianti, "Critical Discourse Analysis in Donald Trump Presidential Campaign to win American's Heart," TELL Journal, Volume 5, No. 2, pp. 8-17, September 2017

[8] U. Flick, An Introduction to Qualitative Article. London: SAGE Publications Ltd. pp. 1, 2009.

[9] J. Mason, Qualitative Researching. London: SAGE Publications Ltd. pp. $45,2002$.

[10] T. van Leeuwen, Discourse and Practice: New Tools for Critical Discourse Analysis. New York: Oxford University Press. pp. 23-54, 2008. 